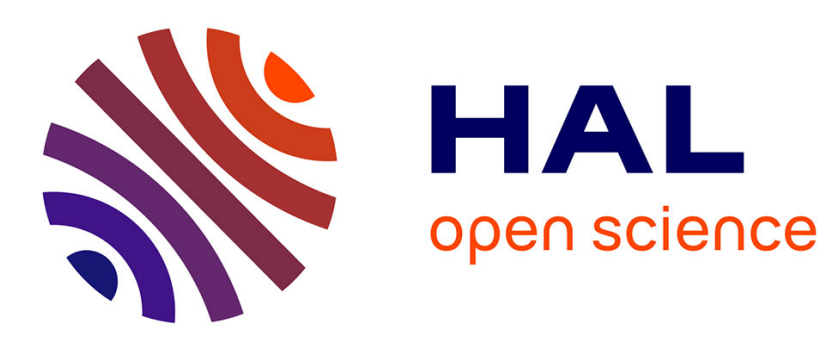

\title{
Outcomes of adrenalectomy in patients with unilateral primary aldosteronism: a review
}

Olivier Steichen, Franck Zinzindohoué, Pierre-François Plouin, Laurence Amar

\section{To cite this version:}

Olivier Steichen, Franck Zinzindohoué, Pierre-François Plouin, Laurence Amar. Outcomes of adrenalectomy in patients with unilateral primary aldosteronism: a review. Hormone and Metabolic Research, 2012, 44 (3), pp.221-227. 10.1055/s-0031-1299681 . hal-01171779

\section{HAL Id: hal-01171779 https://hal.sorbonne-universite.fr/hal-01171779}

Submitted on 6 Jul 2015

HAL is a multi-disciplinary open access archive for the deposit and dissemination of scientific research documents, whether they are published or not. The documents may come from teaching and research institutions in France or abroad, or from public or private research centers.
L'archive ouverte pluridisciplinaire HAL, est destinée au dépôt et à la diffusion de documents scientifiques de niveau recherche, publiés ou non, émanant des établissements d'enseignement et de recherche français ou étrangers, des laboratoires publics ou privés. 


\section{Outcomes of adrenalectomy in patients with unilateral primary aldosteronism: a review}

Short running title: Adrenalectomy for unilateral primary aldosteronism

Olivier Steichen ${ }^{1}$, Franck Zinzindohoué ${ }^{2,3}$, Pierre-François Plouin ${ }^{2,4}$, and Laurence Amar ${ }^{2,5,6}$

${ }^{1}$ Université Pierre et Maris Curie - Paris6, faculté de médecine, Paris, France; Assistance Publique-Hôpitaux de Paris, Hôpital Tenon, Department of Internal Medicine, Paris, France;

${ }^{2}$ Université Paris Descartes, faculté de médecine, Paris, France;

${ }^{3}$ Assistance Publique-Hôpitaux de Paris, Hôpital Européen Georges Pompidou, Department of visceral surgery, Paris, France;

${ }^{4}$ Assistance Publique-Hôpitaux de Paris, Hôpital Européen Georges Pompidou, Hypertension unit, Paris, France;

${ }^{5}$ INSERM U970, Cardiovascular research center, Paris, France;

${ }^{6}$ Assistance Publique-Hôpitaux de Paris, Hôpital Européen Georges Pompidou, Department of Genetics, Paris, France.

Corresponding author: Olivier Steichen

Hôpital Tenon, Department of Internal Medicine,

4 rue de la Chine, F-75020 Paris, France.

Tel: +33 1560178 31; Email: olivier.Steichen@tnn.aphp.fr

For submission for the Proceedings of the $2^{\text {nd }}$ Progress In Primary Aldosteronism meeting 


\begin{abstract}
Aldosterone hypersecretion in primary aldosteronism is unilateral (aldosterone producing adenoma and primary unilateral hyperplasia) or bilateral (idiopathic adrenal hyperplasia). Laparoscopic adrenalectomy is nowadays the preferred approach to treat patients with unilateral primary aldosteronism. We review the outcomes of this intervention in recently published series. Laparoscopic adrenalectomy has a morbidity of 5 to $14 \%$, mortality below $1 \%$ and a mean hospital stay around 3 days. It generally results in the normalization of aldosterone secretion and in a large decrease of blood pressure and antihypertensive medication, but normotension without treatment is only achieved in $42 \%$ of all cases. Normotension following adrenalectomy is more likely in young and lean women with recent low grade hypertension than in obese men with long-standing high grade hypertension or a family history of hypertension. However, individual prediction of the blood pressure outcome is not accurate and predictors of hypertension cure should not be used to select patients for surgery. Age, associated health conditions and preferences of the patient are more relevant to this end.
\end{abstract}

\title{
Keywords
}

Hyperaldosteronism; Adrenalectomy; Minimally Invasive Surgical Procedures; Treatment Outcome; Prognosis; Spironolactone. 


\section{Introduction}

Aldosterone hypersecretion in primary aldosteronism (PA) can be bilateral (idiopathic adrenal hyperplasia or IAH) or unilateral (aldosterone producing adenoma or APA, primary unilateral hyperplasia or PUH). APA is a benign tumor varying in diameter from 7 to $35 \mathrm{~mm}$, with no burden directly related to the space occupied and no risk of malignant transformation [1]. PUH can be diffuse or nodular, with poorly capsulated nodules ranging from microscopic to 6 $\mathrm{mm}$ [2]; in the latter case, the term "unilateral micronodular hyperplasia" may be used.

The goals of treatment in PA are to reduce the morbidity and mortality associated with sustained aldosterone hypersecretion and to improve the patients' quality of life. Health consequences of PA are partly mediated by high BP and low serum potassium. However, the cardiovascular and renal consequences of high BP are more severe in patients with PA than in patients with essential hypertension and similar levels of office BP. It is therefore assumed that sustained aldosterone hypersecretion induces target organ damage through genomic effects mediated by the mineralocorticoid receptor and possibly also by direct, non genomic effects [3].

Treatment objectives in patients with PA are therefore to reduce BP, correct hypokalemia, and to prevent or reverse the cardiovascular and renal alterations directly caused by aldosterone excess. The most logical way to achieve these objectives in patients with unilateral PA is to suppress aldosterone hypersecretion by removing the culprit adrenal. Although aldosterone antagonists have the theoretical disadvantage of preventing only the genomic effects of hyperaldosteronism, they are a suitable alternative in patients who refuse or are not candidate for surgery.

In the following sections we will firstly describe laparoscopic adrenalectomy and its morbidity; secondly we will consider potential alternative interventions to treat unilateral PA; thirdly we will summarize the outcomes and outcome predictors of laparoscopic adrenalectomy in these patients, with reference to medical treatment whenever possible.

\section{Laparoscopic adrenalectomy}

Since the first description of laparoscopic adrenalectomy in 1992 [4], the approach of adrenal surgery has been totally modified and laparoscopy has become the gold standard owing to its lower morbidity and shorter hospital stays. Subsequently, there was a significant increase of the proportion of patients with PA referred for minimally invasive adrenalectomy $(27 \%$ after the introduction of laparoscopy vs. $13 \%$ before, $\mathrm{p}<0.05$ ) [5].

\section{Practical details}

To preclude the risk of hypokalemia-induced arrhythmia during anesthesia, hypokalemic patients should be provided potassium chloride or aldosterone antagonists before surgery [6]. Aldosterone antagonists may also suspend the chronic suppression of aldosterone secretion in the contralateral gland and thereby prevent postoperative hypoaldosteronism. Except comorbidities that could contraindicate laparoscopy per se, there is no technical reason that can avert from unilateral laparoscopic adrenalectomy for PA [7]. Obesity is not a contraindication but operating time correlates with the body mass index for both the transperitoneal or retroperitoneal laparoscopic approaches [8]. 
A large series illustrated the drawbacks and advantages of both approaches [9]. The lateral transperitoneal laparoscopic approach provides a wider exposure and therefore a more complete exploration of the abdomen, whereas the retroperitoneal approach avoids difficult exposure due to adhesions in patients with previous intra-abdominal surgery. This study shows that both approaches have similar outcomes when patients are well selected. The mean operating time of laparoscopic adrenalectomy, the rate of complications and the length of hospital stay vary depending on the indication and the approach used. The mean operative time of laparoscopic adrenalectomy in major institutional series is a between 2 to 3 hours, with a $3.4 \%$ conversion rate to open surgery and a mean hospital stay around 3 days [10].

Laparoscopic adrenalectomy usually requires three to four ports to introduce the instruments. Although technically challenging, laparoscopic single-port surgery using the transumbilical approach is less invasive [11]. Robot-assisted laparoscopy is feasible and safe but more expensive and without documented advantage over conventional laparoscopy $[12,13]$.

Outpatient laparoscopic adrenalectomy is possible [14]. The feasibility conditions are: a disease other than pheochromocytoma, age younger than 65 years, tumor size smaller than 6 $\mathrm{cm}$, no significant cardio-respiratory diseases, first case of the day to be managed in the surgical program, residence less than $30 \mathrm{mn}$ from the hospital by car, and no more than three antihypertensive agents. Over 22 outpatient procedures, the mean operating time was 57 min (range 15-120 min), the most frequent complications were pain and nausea.

\section{Morbidity}

The assessment of surgical morbidity is difficult because of the lack of standardized classification. The pooled mortality in major institutional series published up to 2005 (all indications confounded) was $0.4 \%$ (4/1083) [10]. There was no periprocedural death in the largest series published afterwards (0/520) [15]. The incidence of non fatal complications ranges from 5 to $14 \%$ [6,10]. The most frequent severe complication of laparoscopic adrenalectomy is bleeding requiring transfusion or conversion to open surgery [10]. Compared with open adrenalectomy, the rate of wound, infectious, and pulmonary complications is much lower. In the large series already mentioned, major complications occurred in $1.3 \%$ of patients (7/520: pneumothorax, pneumonia, myocardial infarction, heart failure, blood loss requiring transfusion) and minor complications in $14.4 \%$ (mainly temporary relaxation and/or hypoesthesia of abdominal wall) [15]. Laparoscopic adrenalectomy appears to have a low morbidity but the teams that report their data are usually very experienced, with only one or two specialized surgeons operating all patients. Several cases of major complications outside referral centers have been reported [16].

\section{Alternatives to laparoscopic adrenalectomy}

\section{Other surgical approaches}

Partial adrenalectomy is an alternative to total adrenalectomy. It can be advocated since APA is always benign, and usually small, solitary, and located peripherally on the outer surface of the adrenal cortex. Moreover the adjacent cortex is always functioning, either normal or hyperplasic but never atrophied [17]. However, the rationale of partial adrenalectomy is still disputed since 10 to $25 \%$ of patients with unilateral PA have multiple adjacent nodules and there is no mean to be sure that the bigger lesion is the one responsible of the hypersecretion $[2,18,19]$. A review of 22 series (417 patients) found no unexpected complication of partial 
adrenalectomy and similar surgical outcomes to total adrenalectomy [20]. A recent randomized controlled trial compared partial and total laparoscopic adrenalectomy in 212 patients with APA [21]. The operative time was the same for both approaches but blood losses were significantly higher with partial adrenalectomy, although no transfusion was needed. No major complication was observed with either approach. In the end, partial adrenalectomy is feasible and safe to remove an APA. However, the benefit of this adrenal sparing approach is questionable because the risk of a contralateral tumor that would subsequently require adrenalectomy is very low in patients with an APA. In addition

\section{Non surgical approaches}

Several alternatives to surgery have also been proposed for unilateral PA, such as percutaneous ethanol injection, arterial embolization and more recently percutaneous radiofrequency ablation. The risk of failure and the lack of pathological examination of the adrenal are the main drawback of these techniques. The main exclusion criteria for these procedures are a tumor over $4 \mathrm{~cm}$, out of reach or ill-located (close to the aorta, to the kidney...). The treatment of APA with one to three ethanol injections in five patients cured PA with no other complication than periprocedural pain [22]. Selective adrenal arterial embolization in 33 patients with an APA resulted in a decrease of more than 20UH of the adrenal and the cure rate of PA was $82 \%$ [23]. Most patients experienced flank pain after the procedure, $30 \%$ had fever, $30 \%$ had labile blood pressure, and $15 \%$ had pleural effusion. A series of 24 patients that did undergo CT-guided percutaneous radiofrequency ablation for APA has been reported [24]. Adenomas remained hypolucent without contrast enhancement 3 to 6 months after the procedure in $100 \%$ of the patients and PA was cured in $96 \%(23 / 24$ patients). However the complication rate was $17 \%$ with one small pneumothorax and 3 retroperitoneal hematomas

\section{Outcomes of laparoscopic adrenalectomy}

In this chapter we summarize the results observed in series published since 2000 with $\geq 50$ consecutive patients from a single institution operated for unilateral PA (Table 1). Patients from these series were almost all operated after 1992. Older series are unlikely be representative of current practice because (i) the threshold of hypertension was lowered to 140/90 $\mathrm{mmHg}$ by the JNC5 in 1992 [25]; (ii) the aldosterone:renin ratio is widely used as a screening tool, independently of serum potassium levels, since 1990-1995 [26]; and (iii) laparoscopic adrenalectomy was first reported in 1992 and has become the preferred procedure since then [4]. Owing to these three changes, the clinical profile of PA patients who are sent to surgery is different since 1992 than it was before. It should be noted that patients from these series were assessed after medium term follow up (from a few months to a few years). Evidence is lacking regarding long term outcomes and especially the incidence of recurrent PA.

\section{Potassium and hormonal outcomes}

Surgery cures hypokalemia in $>95 \%$ PA and abolishes aldosterone hypersecretion in $>90 \%$ in patients with unilateral PA [33,35,36,39,43,45]. Persistent hyperaldosteronism is possible after surgery even if adrenal venous sampling (AVS) was performed to ascertain lateralization $[33,45]$, as also reported in smaller series [46-48]. 


\section{Blood-pressure outcome}

Adrenalectomy produces a large decrease in systolic BP (typically -25 to $-40 \mathrm{mmHg}$ ) and in the number of antihypertensive medications prescribed (typically -1 to -2 drug classes) [28$32,37-39,41,44]$. However, BP changes are highly dependent on medication changes and only one study proposed to make a composite outcome out of these two variables [31]. This BP outcome score was neither derived from nor validated on actual patient data; its validity therefore remained to be evaluated. One single study attempted to predict the BP decrease after surgery [32]. However, it did not take medication changes into account and the predictors were weak. For instance, the mean systolic BP decrease was $-25 \mathrm{mmHg}$ after surgery and was only $3 \mathrm{mmHg}$ less $(-22$ instead of $-25 \mathrm{mmHg})$ in patients with a $0.5 \mathrm{mmol} / \mathrm{l}$ higher level of serum potassium before surgery, the most powerful predictor of unfavorable outcomes [32].

Patients should be warned that hypertension is not always cured. The pooled cure rate was $42 \%$ with significant heterogeneity across the series included in this review (Figure 1). Even when adrenalectomy does not cure hypertension, it usually leads to a clinically relevant improvement in the control of hypertension, with lower BP levels and/or less antihypertensive medication required. As a result, hypertension was cured or improved in 74 to $100 \%$ of cases in the series included in this review (Table 1). However, the definition of improvement differed in each series, precluding any pooled estimate of its occurrence.

Many predictors of hypertension cure or persistence have been reported (Table 2). Considering only factors that remained significant in at least one multivariate analysis, hypertension is less likely to be cured after adrenalectomy in patients with unilateral PA who are males, older, with a family history of hypertension, longer duration of hypertension, higher preoperative BP, more drug classes, higher BMI, higher serum potassium concentrations, lower estimated GFR, higher 24-h urinary aldosterone/active renin ratio, or evidence of arteriolosclerosis (Table 2). Of note, having unilateral PA ascertained by AVS was never found to be a predictor of good outcome after surgery $[27,44]$, and has even been associated with worse outcomes [32,33]. Likewise, among patients with unilateral PA diagnosed by AVS, those with higher a lateralization index do not have a better outcome [41].

The relevance of these predictors of hypertension cure for selecting patients for surgery should not be overemphasized. First, the validity of multivariate analyses is threatened by small sample sizes and several studies found no association with hypertension cure for each of the supposed predictors (Table 2). Second, the multivariate models provide only a weak prediction of hypertension cure in individual patients. For example, according to the only prediction model validated to date, number of antihypertensive medication $\leq 2$, a body mass index $\leq 25 \mathrm{~kg} / \mathrm{m}^{2}$, a duration of hypertension $\leq 6$ years and female sex are the best predictors of hypertension cure following adrenalectomy [34]. However, even if none of these features was present in an individual patient, he still had a $25 \%$ probability of being completely cured by an adrenalectomy in the validation cohort. Third, the focus on hypertension cure obscures the likely cure of hypokalemia and hyperaldosteronism and improvement of BP levels achieved even in patients with persistent hypertension after surgery.

No study has directly compared the BP outcome in patients with unilateral PA treated with spironolactone vs. adrenalectomy. However, the increase in serum potassium and decrease in $\mathrm{BP}$ reported in patients with unilateral PA treated with spironolactone are similar to those reported with adrenalectomy, even after a long follow-up duration [49]. 


\section{Other outcomes}

Many studies have shown that the structural heart changes seen in patients with primary aldosteronism - mostly left ventricular hypertrophy - resolve or greatly improve after adrenalectomy [50-54]. Although spironolactone may appear less potent than adrenalectomy in improving left ventricular hypertrophy [51,52,55], studies with longer follow-up have shown that the improvement is slower but similar at the end [54]. A prospective study with long follow up compared PA patients who were treated by adrenalectomy (unilateral disease) or spironolactone (unilateral or bilateral disease) to patients with essential hypertension [56]. The composite endpoint - myocardial infarction, stroke, any type of revascularization procedure, and sustained arrhythmias - did neither differ between these patients with PA who received a specific treatment and patients with essential hypertension, nor did it differ between PA patients treated with adrenalectomy or spironolactone.

Compared to otherwise similar patients with essential hypertension, patients with PA have a relative glomerular hyperfiltration that translates into increased GFR and low grade urinary albumin excretion. These changes are reversible after adrenalectomy in patients with unilateral PA [57-64]. Because of the reversal of relative hyperfiltration, adrenalectomy often unmasks hypertensive kidney disease with moderately decreased GFR. These results are also observed in PA patients treated with spironolactone [58-60,63,64].

Taken as a whole, patients with PA seem to have the same likelihood of glucose metabolism disorders than otherwise similar patients with essential hypertension $[65,66]$. Biochemical indexes of insulin resistance may improve after adrenalectomy [52,59], but this does not appear to translate into a clinically significant improvement of glucose metabolism [65].

One single study evaluated the impact of adrenalectomy on the quality of life in unilateral PA: patients experienced a significant improvement of their subjective well-being, which was lower than in the general population pre-operatively [67]. Unexpectedly, patients with PA treated with spironolactone experience a comparable benefit, although the improvement in quality of life appears to be slower [68].

\section{Benefit - risk and cost - effectiveness assessment}

As we have just seen, reduction of BP, correction of hypokalemia, and prevention or reversal of the cardiovascular and renal alterations can be achieved in patients with unilateral aldosterone hypersecretion by adrenalectomy or by the long-term prescription of aldosterone antagonists. Patients' preferences should be taken into account. Candidates for surgery should be told that the presence of an aldosterone-producing adenoma poses no threat of cancer and informed about the expected outcomes of surgery (benefits and risks, see above).

A primitive cost-effectiveness analysis performed for 50-year old PA patients found that adrenalectomy, with a $35 \%$ cure rate and a $85 \%$ improvement rate, was a cost saving option thanks to lifelong drugs withdrawal [69]. Younger patients have a longer life expectancy and therefore derive an even greater benefit from surgery. They also carry the smallest anesthetic risk. Early diagnosis of unilateral PA is therefore important. Patients with resistant hypertension may also derive a significant benefit, especially if compliance is an issue or if spironolactone is ineffective or not well tolerated. The benefit-risk ratio is more balanced in older patients, especially if their antihypertensive medication has compelling indications and 
must be continued irrespective of BP levels, such as beta-blockers for coronary artery disease or angiotensin-converting enzyme and spironolactone for heart failure.

\section{Conclusion}

Laparascopic adrenalectomy is an appealing therapeutic option for patients with unilateral PA. Some factors are statistically associated with hypertension cure after adrenalectomy but should not be used to select patients for surgery because they fail to identify a significant number of patients that will be cured. Moreover, they ignore the large BP and/or medication decrease and the direct benefit associated with the suppression of aldosterone hypersecretion in patients who remain hypertensive after adrenalectomy. Only the few patients who are at high surgical risk and those with a short life expectancy should be advised against surgery. On the other hand, patients should not be pressed to undergo surgery if they prefer not to, because a fair body of evidence suggests that lifelong treatment with mineralocorticoid antagonists is a valuable alternative to surgery. Other medical options, like aldosterone synthase inhibitors, may also be available in the near future. Best practice is to discuss treatment options with the patient even before performing AVS. 


\section{References}

1. Amar L, Plouin PF, Steichen $O$. Aldosterone-producing adenoma and other surgically correctable forms of primary aldosteronism. Orphanet J Rare Dis 2010;5:9

2. Omura M, Sasano H, Saito J, Yamaguchi K, Kakuta Y, Nishikawa T. Clinical characteristics of aldosterone-producing microadenoma, macroadenoma, and idiopathic hyperaldosteronism in 93 patients with primary aldosteronism. Hypertens Res 2006;29:883-889

3. Connell JM, MacKenzie SM, Freel EM, Fraser R, Davies E. A lifetime of aldosterone excess: long-term consequences of altered regulation of aldosterone production for cardiovascular function. Endocr Rev 2008;29:133-154

4. Gagner M, Lacroix A, Bolte E. Laparoscopic adrenalectomy in Cushing's syndrome and pheochromocytoma. N Engl J Med 1992;327:1033

5. Chavez-Rodriguez J, Pasieka JL. Adrenal lesions assessed in the era of laparoscopic adrenalectomy: a modern day series. Am J Surg 2005;189:581-585; discussion 585586

6. Quinkler M, Stewart PM. Treatment of primary aldosteronism. Best Pract Res Clin Endocrinol Metab 2010;24:923-932

7. Assalia A, Gagner M. Laparoscopic adrenalectomy. Br J Surg 2004;91:1259-1274

8. Naya Y, Nagata M, Ichikawa T, Amakasu M, Omura M, Nishikawa T, Yamaguchi K, Ito $H$. Laparoscopic adrenalectomy: comparison of transperitoneal and retroperitoneal approaches. BJU Int 2002;90:199-204

9. Berber E, Tellioglu G, Harvey A, Mitchell J, Milas M, Siperstein A. Comparison of laparoscopic transabdominal lateral versus posterior retroperitoneal adrenalectomy. Surgery 2009;146:621-625; discussion 625-626

10. $\quad$ Brunt LM. Minimal access adrenal surgery. Surg Endosc 2006;20:351-361

11. Yuge K, Miyajima A, Hasegawa M, Miyazaki Y, Maeda T, Takeda T, Takeda A, Miyashita K, Kurihara I, Shibata H, Kikuchi E, Oya M. Initial experience of transumbilical laparoendoscopic single-site surgery of partial adrenalectomy in patient with aldosterone-producing adenoma. BMC Urol 2010;10:19

12. Cadiere GB, Himpens J, Germay O, Izizaw R, Degueldre M, Vandromme J, Capelluto E, Bruyns J. Feasibility of robotic laparoscopic surgery: 146 cases. World J Surg 2001;25:1467-1477

13. Hyams ES, Stifelman MD. The role of robotics for adrenal pathology. Curr Opin Urol 2009; 19:89-96

14. Ramirez-Plaza CP, Gallego Perales JL, Camero NM, Rodriguez-Canete A, BondiaNavarro JA, Santoyo-Santoyo J. Outpatient laparoscopic adrenalectomy: a new step ahead. Surg Endosc 2011;25:2570-2573

15. Walz MK, Alesina PF, Wenger FA, Deligiannis A, Szuczik E, Petersenn S, Ommer A, Groeben H, Peitgen K, Janssen OE, Philipp T, Neumann HP, Schmid KW, Mann K. Posterior retroperitoneoscopic adrenalectomy--results of 560 procedures in 520 patients. Surgery 2006;140:943-948; discussion 948-950

16. Tessier DJ, Iglesias R, Chapman WC, Kercher K, Matthews BD, Gorden DL, Brunt $L M$. Previously unreported high-grade complications of adrenalectomy. Surg Endosc 2009;23:97-102

17. Boulkroun S, Samson-Couterie B, Dzib JF, Lefebvre H, Louiset E, Amar L, Plouin PF, Lalli E, Jeunemaitre X, Benecke A, Meatchi T, Zennaro MC. Adrenal cortex 
remodeling and functional zona glomerulosa hyperplasia in primary aldosteronism. Hypertension 2010;56:885-892

18. Omura M, Sasano H, Fujiwara T, Yamaguchi K, Nishikawa T. Unique cases of unilateral hyperaldosteronemia due to multiple adrenocortical micronodules, which can only be detected by selective adrenal venous sampling. Metabolism 2002;51:350355

19. Ishidoya S, Ito A, Sakai K, Satoh M, Chiba Y, Sato F, Arai Y. Laparoscopic partial versus total adrenalectomy for aldosterone producing adenoma. J Urol 2005;174:40-43

20. Kaye DR, Storey BB, Pacak K, Pinto PA, Linehan WM, Bratslavsky G. Partial adrenalectomy: underused first line therapy for small adrenal tumors. J Urol 2010;184:18-25

21. Fu B, Zhang X, Wang GX, Lang B, Ma X, Li HZ, Wang BJ, Shi TP, Ai X, Zhou HX, Zheng $T$. Long-term results of a prospective, randomized trial comparing retroperitoneoscopic partial versus total adrenalectomy for aldosterone producing adenoma. J Urol 2011;185:1578-1582

22. Minowada S, Fujimura T, Takahashi N, Kishi H, Hasuo K, Minami M. Computed tomography-guided percutaneous acetic acid injection therapy for functioning adrenocortical adenoma. J Clin Endocrinol Metab 2003;88:5814-5817

23. Hokotate H, Inoue H, Baba Y, Tsuchimochi S, Nakajo M. Aldosteronomas: experience with superselective adrenal arterial embolization in 33 cases. Radiology 2003;227:401-406

24. Liu SY, Ng EK, Lee PS, Wong SK, Chiu PW, Mui WL, So WY, Chow FC. Radiofrequency ablation for benign aldosterone-producing adenoma: a scarless technique to an old disease. Ann Surg 2010;252:1058-1064

25. The fifth report of the Joint National Committee on Detection, Evaluation, and Treatment of High Blood Pressure (JNC V). Arch Intern Med 1993;153:154-183

26. Mulatero P, Stowasser M, Loh KC, Fardella CE, Gordon RD, Mosso L, GomezSanchez $C E$, Veglio $F$, Young $W F$, Jr. Increased diagnosis of primary aldosteronism, including surgically correctable forms, in centers from five continents. J Clin Endocrinol Metab 2004;89:1045-1050

27. Sawka AM, Young WF, Thompson GB, Grant CS, Farley DR, Leibson C, van Heerden $J A$. Primary aldosteronism: factors associated with normalization of blood pressure after surgery. Ann Intern Med 2001;135:258-261

28. Lumachi F, Ermani M, Basso SM, Armanini D, Iacobone M, Favia G. Long-term results of adrenalectomy in patients with aldosterone-producing adenomas: multivariate analysis of factors affecting unresolved hypertension and review of the literature. Am Surg 2005;71:864-869

29. Satoh $F$, Abe T, Tanemoto M, Nakamura M, Abe M, Uruno A, Morimoto R, Sato A, Takase K, Ishidoya S, Arai Y, Suzuki T, Sasano H, Ishibashi T, Ito S. Localization of aldosterone-producing adrenocortical adenomas: significance of adrenal venous sampling. Hypertens Res 2007;30:1083-1095

30. Pang TC, Bambach C, Monaghan JC, Sidhu SB, Bune A, Delbridge LW, Sywak MS. Outcomes of laparoscopic adrenalectomy for hyperaldosteronism. ANZ J Surg 2007;77:768-773

31. Rossi GP, Bolognesi M, Rizzoni D, Seccia TM, Piva A, Porteri E, Tiberio GA, Giulini SM, Agabiti-Rosei E, Pessina AC. Vascular remodeling and duration of hypertension predict outcome of adrenalectomy in primary aldosteronism patients. Hypertension 2008;51:1366-1371 
32. Letavernier E, Peyrard S, Amar L, Zinzindohoue F, Fiquet B, Plouin PF. Blood pressure outcome of adrenalectomy in patients with primary hyperaldosteronism with or without unilateral adenoma. J Hypertens 2008;26:1816-1823

33. Zarnegar R, Lee J, Brunaud L, Lindsay S, Kebebew E, Clark OH, Duh QY. Good blood pressure control on antihypertensives, not only response to spironolactone, predicts improved outcome after adrenalectomy for aldosteronoma. Surgery 2007;142:921-929; discussion 921-929

34. Zarnegar R, Young WF, Jr., Lee J, Sweet MP, Kebebew E, Farley DR, Thompson GB, Grant CS, Clark $\mathrm{OH}$, Duh $Q Y$. The aldosteronoma resolution score: predicting complete resolution of hypertension after adrenalectomy for aldosteronoma. Ann Surg 2008;247:511-518

35. Walz MK, Gwosdz R, Levin SL, Alesina PF, Suttorp AC, Metz KA, Wenger FA, Petersenn S, Mann K, Schmid KW. Retroperitoneoscopic adrenalectomy in Conn's syndrome caused by adrenal adenomas or nodular hyperplasia. World J Surg 2008;32:847-853

36. White ML, Gauger PG, Doherty GM, Cho KJ, Thompson NW, Hammer GD, Miller $B S$. The role of radiologic studies in the evaluation and management of primary hyperaldosteronism. Surgery 2008;144:926-933; discussion 933

37. Mourad JJ, Girerd X, Milliez P, Lopez-Sublet M, Lejeune S, Safar ME. Urinary aldosterone-to-active-renin ratio: a useful tool for predicting resolution of hypertension after adrenalectomy in patients with aldosterone-producing adenomas. Am J Hypertens 2008;21:742-747

38. Chiou TT, Chiang PH, Fuh M, Liu RT, Lee WC, Lee WC, Ng HY, Tsai YC, Chuang $F R$, Huang CC, Lee CT. Factors determining cardiovascular and renal outcomes after adrenalectomy in patients with aldosterone-producing adrenal adenoma. Tohoku J Exp Med 2009;218:17-24

39. Campagnacci R, Crosta F, De Sanctis A, Baldarelli M, Giacchetti G, Paganini AM, Coletta $M$, Guerrieri $M$. Long-term results of laparoscopic adrenalectomy for primary aldosteronism. J Endocrinol Invest 2009;32:57-62

40. Wu VC, Chueh SC, Chang HW, Lin LY, Liu KL, Lin YH, Ho YL, Lin WC, Wang SM, Huang KH, Hung KY, Kao TW, Lin SL, Yen RF, Chen YM, Hsieh BS, Wu KD. Association of kidney function with residual hypertension after treatment of aldosterone-producing adenoma. Am J Kidney Dis 2009;54:665-673

41. Murashima M, Trerotola SO, Fraker DL, Han D, Townsend RR, Cohen DL. Adrenal venous sampling for primary aldosteronism and clinical outcomes after unilateral adrenalectomy: a single-center experience. J Clin Hypertens (Greenwich) 2009;11:316-323

42. Tresallet C, Salepcioglu H, Godiris-Petit G, Hoang C, Girerd X, Menegaux F. Clinical outcome after laparoscopic adrenalectomy for primary hyperaldosteronism: the role of pathology. Surgery 2010;148:129-134

43. Wang B, Zhang G, Ouyang J, Deng X, Shi T, Ma X, Li H, Ju Z, Wang C, Wu Z, Liu S, Zhang $X$. Association of DNA polymorphisms within the CYP11B2/CYP11B1 locus and postoperative hypertension risk in the patients with aldosterone-producing adenomas. Urology 2010;76:1018 e1011-1017

44. Waldmann J, Maurer L, Holler J, Kann PH, Ramaswamy A, Bartsch DK, Langer P. Outcome of Surgery for Primary Hyperaldosteronism. World J Surg 2011

45. Ishidoya S, Kaiho Y, Ito A, Morimoto R, Satoh F, Ito S, Ishibashi T, Nakamura Y, Sasano H, Arai Y. Single-center outcome of laparoscopic unilateral adrenalectomy for patients with primary aldosteronism: lateralizing disease using results of adrenal venous sampling. Urology 2011;78:68-73 
46. Stowasser M, Gordon RD. Primary aldosteronism--careful investigation is essential and rewarding. Mol Cell Endocrinol 2004;217:33-39

47. Kline GA, Harvey A, Jones C, Hill MH, So B, Scott-Douglas N, Pasieka JL. Adrenal vein sampling may not be a gold-standard diagnostic test in primary aldosteronism: final diagnosis depends upon which interpretation rule is used. Variable interpretation of adrenal vein sampling. Int Urol Nephrol 2008;40:1035-1043

48. Lau JH, Sze WC, Reznek RH, Matson M, Sahdev A, Carpenter R, Berney DM, Akker SA, Chew SL, Grossman AB, Monson JP, Drake WM. A Prospective Evaluation Of Postural Stimulation Testing, Computed Tomography And Adrenal Vein Sampling In The Differential Diagnosis Of Primary Aldosteronism. Clin Endocrinol (Oxf) 2011

49. Ghose RP, Hall PM, Bravo EL. Medical management of aldosterone-producing adenomas. Ann Intern Med 1999;131:105-108

50. Yoshitomi Y, Nishikimi T, Abe H, Yoshiwara F, Suzuki T, Ashizawa A, Nagata S, Kuramochi M, Matsuoka H, Omae T. Comparison of changes in cardiac structure after treatment in secondary hypertension. Hypertension 1996;27:319-323

51. Rossi GP, Sacchetto A, Visentin P, Canali C, Graniero GR, Palatini P, Pessina AC. Changes in left ventricular anatomy and function in hypertension and primary aldosteronism. Hypertension 1996;27:1039-1045

52. Giacchetti G, Ronconi V, Turchi F, Agostinelli L, Mantero F, Rilli S, Boscaro M. Aldosterone as a key mediator of the cardiometabolic syndrome in primary aldosteronism: an observational study. J Hypertens 2007;25:177-186

53. Lin YH, Huang KH, Lee JK, Wang SM, Yen RF, WuVC, Chung SD, Liu KL, Chueh $S C$, Lin $L Y$, Ho $Y L$, Chen $M F$, Wu $K D$. Factors influencing left ventricular mass regression in patients with primary aldosteronism post adrenalectomy. J Renin Angiotensin Aldosterone Syst 2011;12:48-53

54. Catena C, Colussi G, Lapenna R, Nadalini E, Chiuch A, Gianfagna P, Sechi LA. Long-term cardiac effects of adrenalectomy or mineralocorticoid antagonists in patients with primary aldosteronism. Hypertension 2007;50:911-918

55. Rossi GP, Sacchetto A, Pavan E, Palatini P, Graniero GR, Canali C, Pessina AC. Remodeling of the left ventricle in primary aldosteronism due to Conn's adenoma. Circulation 1997;95:1471-1478

56. Catena C, Colussi G, Nadalini E, Chiuch A, Baroselli S, Lapenna R, Sechi LA. Cardiovascular outcomes in patients with primary aldosteronism after treatment. Arch Intern Med 2008;168:80-85

57. Ribstein J, Du Cailar G, Fesler P, Mimran A. Relative glomerular hyperfiltration in primary aldosteronism. J Am Soc Nephrol 2005;16:1320-1325

58. Sechi LA, Novello M, Lapenna R, Baroselli S, Nadalini E, Colussi GL, Catena C. Long-term renal outcomes in patients with primary aldosteronism. Jama 2006;295:2638-2645

59. Catena C, Colussi G, Nadalini E, Chiuch A, Baroselli S, Lapenna R, Sechi LA. Relationships of plasma renin levels with renal function in patients with primary aldosteronism. Clin J Am Soc Nephrol 2007;2:722-731

60. Sechi LA, Di Fabio A, Bazzocchi M, Uzzau A, Catena C. Intrarenal hemodynamics in primary aldosteronism before and after treatment. J Clin Endocrinol Metab 2009;94:1191-1197

61. Reincke M, Rump LC, Quinkler M, Hahner S, Diederich S, Lorenz R, Seufert J, Schirpenbach C, Beuschlein F, Bidlingmaier M, Meisinger C, Holle R, Endres S. Risk factors associated with a low glomerular filtration rate in primary aldosteronism. $\mathrm{J}$ Clin Endocrinol Metab 2009;94:869-875 
62. Pimenta E, Gordon RD, Ahmed AH, Cowley D, Robson D, Kogovsek C, Stowasser M. Unilateral adrenalectomy improves urinary protein excretion but does not abolish its relationship to sodium excretion in patients with aldosterone-producing adenoma. $\mathbf{J}$ Hum Hypertens 2010

63. Wu VC, Kuo CC, Wang SM, Liu KL, Huang KH, Lin YH, Chu TS, Chang HW, Lin CY, Tsai CT, Lin LY, Chueh SC, Kao TW, Chen YM, Chiang WC, Tsai TJ, Ho YL, Lin SL, Wang $W J, W u K D$. Primary aldosteronism: changes in cystatin C-based kidney filtration, proteinuria, and renal duplex indices with treatment. J Hypertens 2011;29:1778-1786

64. Wu VC, Yang SY, Lin JW, Cheng BW, Kuo CC, Tsai CT, Chu TS, Huang KH, Wang $S M$, Lin YH, Chiang CK, Chang HW, Lin CY, Lin LY, Chiu JS, Hu FC, Chueh SC, Ho $Y L$, Liu $K L$, Lin $S L$, Yen $R F$, Wu KD. Kidney impairment in primary aldosteronism. Clin Chim Acta 2011;412:1319-1325

65. Matrozova J, Steichen O, Amar L, Zacharieva S, Jeunemaitre X, Plouin PF. Fasting plasma glucose and serum lipids in patients with primary aldosteronism: a controlled cross-sectional study. Hypertension 2009;53:605-610

66. Somloova Z, Widimsky J, Jr., Rosa J, Wichterle D, Strauch B, Petrak O, Zelinka T, Vlkova J, Masek M, Dvorakova J, Holaj R. The prevalence of metabolic syndrome and its components in two main types of primary aldosteronism. J Hum Hypertens 2010;24:625-630

67. Sukor N, Gordon RD, Ku YK, Jones M, Stowasser M. Role of unilateral adrenalectomy in bilateral primary aldosteronism: a 22-year single center experience. J Clin Endocrinol Metab 2009;94:2437-2445

68. Ahmed AH, Gordon RD, Sukor N, Pimenta E, Stowasser M. Quality of Life in Patients with Bilateral Primary Aldosteronism before and during Treatment with Spironolactone and/or Amiloride, Including a Comparison with Our Previously Published Results in Those with Unilateral Disease Treated Surgically. J Clin Endocrinol Metab 2011;96:2904-2911

69. Sywak M, Pasieka JL. Long-term follow-up and cost benefit of adrenalectomy in patients with primary hyperaldosteronism. Br J Surg 2002;89:1587-1593 
Table 1. Series published since 2000 with blood pressure follow-up after adrenalectomy for unilateral PA in at least 50 consecutive patients

Figure 1. Hypertension cure rate after adrenalectomy for unilateral PA in series published since 2000 with at least 50 consecutive patients

Table 2. Predictors of hypertension cure following adrenalectomy in series published since 2000 and including at least 50 consecutive patients 
Table 1. Series published since 2000 with blood pressure follow-up after adrenalectomy for unilateral PA in at least 50 consecutive patients

\begin{tabular}{|c|c|c|c|c|c|}
\hline Institution & $\begin{array}{l}\text { Years of } \\
\text { inclusion }\end{array}$ & $\begin{array}{l}\text { Patients } \\
\text { followed }\end{array}$ & $\begin{array}{l}\text { Patients } \\
\text { cured }\end{array}$ & Definition of improvement & $\begin{array}{l}\text { Patients } \\
\text { cured or } \\
\text { improved }\end{array}$ \\
\hline Rochester, Mayo Clinic [23] & 1993-1999 & 93 & $31(33 \%)$ & BP decrease or fewer drugs & $92(99 \%)$ \\
\hline Padova, University hospital [24] & $1988-2002$ & 98 & $71(72 \%)$ & Less medication required for BP control & $95(97 \%)$ \\
\hline $\begin{array}{l}\text { Tokyo and Yokohama, Social Insurance } \\
\text { Central General Hospital and Yokohama } \\
\text { Rosai Hospital [25] }\end{array}$ & $1995-2005$ & 69 & $44(64 \%)$ & None provided & $\begin{array}{c}\text { Not } \\
\text { available }\end{array}$ \\
\hline Sendai, Tohoku University Hospital [26] & $\begin{array}{l}\text { Not } \\
\text { available }\end{array}$ & 61 & $23(38 \%)$ & BP decrease & $61(100 \%)$ \\
\hline $\begin{array}{l}\text { Sydney, University of Sydney Endocrine } \\
\text { Surgical Unit [27] }\end{array}$ & $1995-2005$ & 53 & $18(34 \%)$ & $\begin{array}{c}\text { BP }<140 / 90 \mathrm{mmHg} \text { with equal or fewer } \\
\text { drugs, or hypertensive but requiring fewer } \\
\text { drugs }\end{array}$ & $48(91 \%)$ \\
\hline Padova, University hospital [28] & $\begin{array}{l}\text { Not } \\
\text { available }\end{array}$ & 50 & $15(30 \%)$ & $\begin{array}{c}\mathrm{BP}<140 / 90 \mathrm{mmHg} \text { or fall of systolic and/or } \\
\text { diastolic BP }>10 \% \text {, on the same or reduced } \\
\text { number of drugs and/or daily doses }\end{array}$ & $50(100 \%)$ \\
\hline Paris, HEGP [29] & 1993-2004 & 168 & $53(32 \%)$ & $\begin{array}{c}\text { Systolic } \mathrm{BP}<140 \mathrm{mmHg} \text { and/or diastolic } \\
\mathrm{BP}<90 \mathrm{mmHg} \text { or diastolic BP decrease } \geq \\
15 \mathrm{mmHg}, \text { for patients remaining on the } \\
\text { same or less medication }\end{array}$ & $124(74 \%)$ \\
\hline $\begin{array}{l}\text { San Francisco, University of California } \\
\text { San Francisco }[30,31]\end{array}$ & 1994-2005 & 100 & $35(35 \%)$ & BP decrease or fewer drugs & $95(92 \%)$ \\
\hline Essen, Kliniken Essen-Mitte [32] & 1994-2007 & 160 & $48(30 \%)^{a}$ & $\begin{array}{c}\text { Systolic } \mathrm{BP} \leq 140 \mathrm{mmHg} \text { with reduced } \\
\text { medication }\end{array}$ & $139(87 \%)$ \\
\hline Ann Harbor, University of Michigan [33] & 1996-2007 & 62 & $10(16 \%)$ & $\mathrm{BP}<140 / 90 \mathrm{mmHg}$ with medication & $53(85 \%)$ \\
\hline Paris, Broussais [34] & 1997-1999 & 58 & $23(40 \%)$ & $\mathrm{BP}<140 / 90 \mathrm{mmHg}$ with medication & $43(74 \%)$ \\
\hline $\begin{array}{l}\text { Taiwan, Chang Gung University College } \\
\text { of Medicine [35] }\end{array}$ & $1987-2006$ & 52 & $32(62 \%)$ & None provided & $\begin{array}{c}\text { Not } \\
\text { available }\end{array}$ \\
\hline Ancona, Polytechnic University of & 1994-2006 & 54 & $21(39 \%)^{a}$ & Systolic BP $\leq 140 \mathrm{mmHg}$ with reduced & $47(87 \%)$ \\
\hline
\end{tabular}




\begin{tabular}{|c|c|c|c|c|c|}
\hline Marche [36] & & & & medication & \\
\hline Taiwan, University Hospital [37] & 1999-2007 & 150 & $95(63 \%)^{b}$ & BP decrease with lower dosages of drugs & $145(97 \%)$ \\
\hline $\begin{array}{l}\text { Philadelphia, University of Pensylvania } \\
\text { [38] }\end{array}$ & $2001-2007$ & 57 & $12(21 \%)$ & $\begin{array}{c}\text { Systolic BP decrease }>10 \mathrm{mmHg} \text { with the } \\
\text { same number of drugs, or SBP within } 10 \\
\text { mmHg from preoperative value with fewer } \\
\text { drugs }\end{array}$ & $51(89 \%)$ \\
\hline Paris, Pitié Salpétrière [39] & $1997-2008$ & 57 & $33(58 \%)$ & Fewer drugs & $56(98 \%)$ \\
\hline Wuhan, Tongji Hospitals [40] & $2002-2007$ & 93 & $54(58 \%)$ & None provided & $\begin{array}{c}\text { Not } \\
\text { available }\end{array}$ \\
\hline $\begin{array}{l}\text { Marburg, University Hospital Giessen and } \\
\text { Marburg [41] }\end{array}$ & $1993-2009$ & 54 & $20(37 \%)$ & None provided & $\begin{array}{c}\text { Not } \\
\text { available }\end{array}$ \\
\hline
\end{tabular}

BP: blood pressure. Patients cured if BP $<140 / 90 \mathrm{mmHg}$ without medication except ${ }^{\mathrm{a}}$ systolic $\mathrm{BP}<140$ mmHg without medication and ${ }^{\mathrm{b}} \mathrm{BP}<$ $140 / 90 \mathrm{mmHg}$ without medication in more than $75 \%$ of measurements 
Table 2. Predictors of hypertension cure following adrenalectomy in series published since 2000 and including at least 50 consecutive patients

\begin{tabular}{|c|c|c|c|}
\hline Risk factor & $\begin{array}{l}\text { Associated in univariate } \\
\text { analysis }\end{array}$ & $\begin{array}{l}\text { Associated in } \\
\text { multivariate analysis }\end{array}$ & Not associated \\
\hline Being female & $\begin{array}{c}4 \text { studies [32] [27] [39] } \\
\text { [36] }\end{array}$ & 1 study $[31]$ & $\begin{array}{c}7 \text { studies [37] [28] [24] } \\
{[23][38][41][40]}\end{array}$ \\
\hline Younger age & $\begin{array}{c}5 \text { studies [32] [39] [36] } \\
{[23][41]} \\
\end{array}$ & $\begin{array}{c}5 \text { studies [37] [31] [27] } \\
{[24][34]} \\
\end{array}$ & $\begin{array}{c}4 \text { studies [28] [35] [38] } \\
{[40]}\end{array}$ \\
\hline Absence of diabetes & 1 study [37] & No study & No study \\
\hline Absence of cardiovascular disease & 1 study [37] & No study & No study \\
\hline $\begin{array}{l}\text { No history of essential hypertension in first- } \\
\text { degree relatives }\end{array}$ & 2 studies [37] [36] & 2 studies [23] [40] & 3 studies [31] [39] [24] \\
\hline Shorter duration of hypertension before surgery & $\begin{array}{c}5 \text { studies [32] [31] [39] } \\
{[36][23]} \\
\end{array}$ & $\begin{array}{c}5 \text { studies [37] [28] [24] } \\
{[40][41]} \\
\end{array}$ & 2 studies [35] [34] \\
\hline Lower preoperative BP & 3 studies [28] [39] [35] & 2 studies [37] [40] & $\begin{array}{c}5 \text { studies [27] [24] [23] } \\
{[38][41]} \\
\end{array}$ \\
\hline $\begin{array}{l}\text { Lower number of prescribed antihypertensive } \\
\text { classes }\end{array}$ & $\begin{array}{c}5 \text { studies [27] [39] [36] } \\
{[24][38]}\end{array}$ & 3 studies [31] [23] [41] & $\begin{array}{c}4 \text { studies [37] [28] [35] } \\
\text { [40] }\end{array}$ \\
\hline Preoperative normalization of BP & 1 study [30] & No study & No study \\
\hline $\begin{array}{l}\text { Preoperative normalization of } \mathrm{BP} \text { on } \\
\text { monotherapy with high-dose spironolactone }\end{array}$ & No study & No study & 2 studies [30] [24] \\
\hline Lower body mass index or weight & 3 study [28] [39] [41] & 2 studies [37] [31] & 2 studies [24] [40] \\
\hline Low serum potassium levels & 1 study [31] & 1 study [34] & $\begin{array}{c}9 \text { studies [37] [27] [28] } \\
{[39][35][24][23][41]} \\
{[40]}\end{array}$ \\
\hline $\begin{array}{l}\text { Higher estimated GFR or lower creatinine } \\
\text { concentration }\end{array}$ & 2 studies [39] [34] & 2 studies [37] [41] & $\begin{array}{c}4 \text { studies [35] [24] [38] } \\
\text { [40] }\end{array}$ \\
\hline Presence of proteinuria & No study & No study & 1 study [37] \\
\hline Higher left ventricular mass index & 1 study [34] & No study & 1 study [28] \\
\hline Presence of arteriolosclerosis & No study & 1 study [28] & No study \\
\hline
\end{tabular}




\begin{tabular}{|c|c|c|c|}
\hline Higher urinary aldosterone excretion & 1 study [23] & No study & 1 study [34] \\
\hline $\begin{array}{l}\text { Higher 24-h urinary aldosterone/active renin } \\
\text { ratio }\end{array}$ & No study & 1 study [34] & No study \\
\hline Higher plasma aldosterone concentration & No study & No study & $\begin{array}{c}10 \text { studies [37] [31] [27] } \\
\text { [39] [35] [24] [34] [38] } \\
\text { [41] [40] }\end{array}$ \\
\hline Lower plasma renin concentration or activity & 2 studies [31] [39] & No study & $\begin{array}{c}5 \text { studies [37] [35] [34] } \\
{[38][40]}\end{array}$ \\
\hline Higher aldosterone:renin ratio & 2 studies [34] [23] & No study & $\begin{array}{l}8 \text { studies [37] [31] [28] } \\
\text { [39] [35] [24] [38] [40] }\end{array}$ \\
\hline Furosemide upright test & 1 study [25] & No study & No study \\
\hline Captopril test & 1 study [25] & No study & No study \\
\hline Typical adenoma on imaging or pathology & 2 studies [32] [31] & No study & $\begin{array}{c}4 \text { studies [37] [39] [23] } \\
{[38]}\end{array}$ \\
\hline Larger adenoma & 3 studies [31] [39] [34] & No study & $\begin{array}{c}5 \text { studies [27] [28] [24] } \\
{[41][40]}\end{array}$ \\
\hline Smaller adenoma & 1 study [25] & No study & $\begin{array}{c}5 \text { studies [27] [28] [24] } \\
{[41][40]} \\
\end{array}$ \\
\hline Smaller adrenal gland & 1 study [27] & No study & No study \\
\hline $\begin{array}{l}\text { Lateralization established by CT rather than } \\
\text { AVS }\end{array}$ & 1 study [30] [29] & No study & 2 studies [23] [41] \\
\hline Higher lateralization index & No study & No study & 1 study [38] \\
\hline Adenomectomy (vs. adrenalectomy) & 1 study [32] & No study & No study \\
\hline
\end{tabular}

BP: blood pressure; GFR: glomerular filtration rate; CT: computed tomography; AVS: adrenal venous sampling 


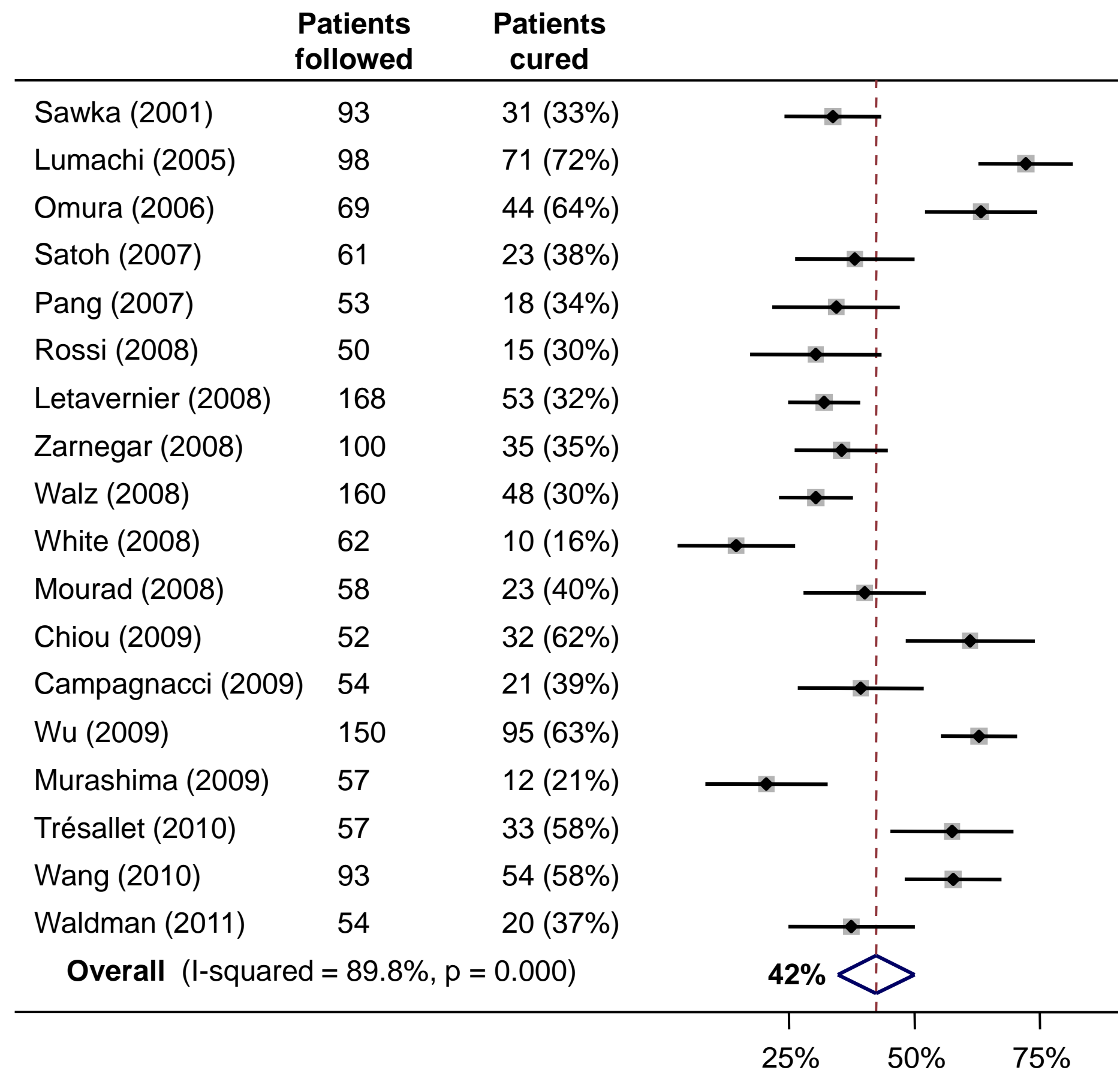

